\title{
Correction to: Pink oyster mushroom Pleurotus flabellatus mycelium produced by an airlift bioreactor-the evidence of potent in vitro biological activities
}

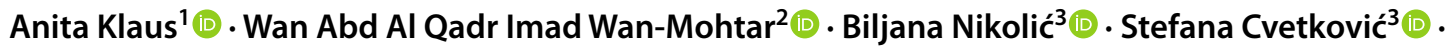 \\ Jovana Vunduk ${ }^{1}$ (D)
}

Published online: 24 January 2021

(c) Springer Nature B.V. 2021

\section{Correction to: \\ World Journal of Microbiology and Biotechnology (2021) 37:17 \\ https://doi.org/10.1007/s11274-020-02980-6}

Unfortunately, author has missed to include the following text in the Acknowledgement section "We also thank Dr Shaiful Azuar Mohamad and the team from Nuclear Malaysia for providing the mushroom polysaccharide (endo and exo) samples in 2018. Any future publications regarding the samples provided should not be made without his consent." The updated complete Acknowledgement is provided below:

Acknowledgement This work was supported by a contract for the realization and funding of research work in 2020, between the University of Belgrade-Faculty of Agriculture and the Ministry of Education, Science and Technological Development of the Republic of Serbia, contract number: 451-03-68/2020-14/200116. We thank Dragana Četojević-Simin, Oncology Institute of Vojvodina, Sremska Kamenica, Serbia, and Snežana Marković, Laboratory of Cell and Molecular Biology, Faculty of Science, University of Kragujevac, Serbia, for providing MRC-5 and
HCT116 cells, respectively. Both lines were obtained in 2015. The sample logistic was sponsored by GERAN RUSATU (Southeast and South Asia and Taiwan Universities) JOINT RESEARCH 2020: ST002-2020 to Dr. Wan-Mohtar. We also thank Dr Shaiful Azuar Mohamad and the team from Nuclear Malaysia for providing the mushroom polysaccharide (endo and exo) samples in 2018. Any future publications regarding the samples provided should not be made without his consent.

Publisher's Note Springer Nature remains neutral with regard to jurisdictional claims in published maps and institutional affiliations.
The original article can be found online at https://doi.org/10.1007/ s11274-020-02980-6.

Anita Klaus

aklaus@agrif.bg.ac.rs

1 Faculty of Agriculture, Institute for Food Technology and Biochemistry, University of Belgrade, 6 Nemanjina Street, 11080 Belgrade, Serbia

2 Functional Omics and Bioprocess Development Laboratory, Faculty of Science, Institute of Biological Sciences, University of Malaya, 50603 Kuala Lumpur, Malaysia

3 Department of Microbiology, Faculty of Biology, University of Belgrade, 16 Studentski Trg, 11000 Belgrade, Serbia 